\title{
The effect Analysis of Grammar Mastery towards Writing English Skill
}

\author{
Jimmi \\ ABA BSI Jakarta \\ Email: jimmi.jmm@bsi.ac.id
}

\begin{abstract}
The objective of this research is to know the correlation between grammar mastery and writing English skill of student Grade X SMK Selagan Jaya Jakarta. The population is taken from SMK Selagan Jaya Jakarta. The sample of research is twenty students. The method used correlative descriptive by sampling randomly technique which is writing test. The data is taken from grammar mastery 56 as lowest score, 96 as highest score; $X=73,3$ and $S=15,46$. For writing English skill the lowest score is 52, the highest 92; $X=67,6$, and $S=13,65$. The next step is to know the effect of grammar mastery towards writing English skill, the writer uses correlation product moment by finding rxy $=0$, 9889 on table significant 0,05 bigger than $F t_{\text {able }}$ shown 0 , 444. This criteria's shows the correlation was high. So, this research have been succeed to reject of zero hypothesis which is said no effect between grammar mastery towards writing English skill of student grade $X$ SMK Selagan Jaya Jakarta. This result of the result been done can be useful for English teacher to increase their competence of grammar mastery and provide an appropriate task for students.
\end{abstract}

\section{Keyword: grammar mastery, writing English, quantitative descriptive}

\section{INTRDUCTION}

Nowadays, English cannot be ignored due to have important role to reach something or to be priority skill to compete in this era. People should have something they have mastered to get something they looked for. It is known also English as global language which is used almost more than half people around the world as international communication. Besides that, this language is a tool to reach economy and trading purposes, the relations of the nations, social and culture, and education for brighter career. Mastery grammar is an important condition to be learnt whether personal or society of nationality in preparing any challenge would be come in future. Successful communication in situations which simulate real life is the best test of mastery of language.

The grammar mastery is an acquired by any various learning program in school such as student learn grammar through puzzle, guessing word, or role play. These activities will stimulate their competence to do observation of grammar had been studied. Reflection in the past shown that English learning still left far behind of the goal needed. One of the issues of student learning is the mastery of grammar in writing skill. This can be found of student result which is still very lack of it. The condition, off course, as reflection of student result whereas still conventional and do not focus on student competence itself, how the learning should be.

Generally teacher is an agent of learning at present time. This means the teacher must able to make learning become contextual involving student directly and actively. No matter how good the learning mainly is, if teacher do not able to create in delivery well, so the mainly will be not reached by student anyway. It will affect the student been bored, lack of responsibility, excitement of studying. Teacher is strived to be able to design the learning become interesting, effective, innovative, and at the end it will increase student's creativity.

The success of student learning is marked by student achievement. This is all people needed of achievement in learning process even though, somehow, still not all students can reach the learning successful. The learning situation in the class, especially for vocational high student, English is become less effective during teaching learning process. It because students unable or lack of English so cannot do the English exercises given by the hands book or teacher.

Many causes can make student lack of English one of them is lack of confidence they have and afraid while make something mistake. The students have to face their afraid when the teacher begins to point them one by one whether to answer the questions or to write the answer in white board. This still existed during the processes appear in the class. If this situation is continuously, of course will be decreased student's achievement. The proses teaching and learning between teacher and student are less effective. The learning achievement had been planned fail.

Student must concern about writing skill as their one of competence in English course. They realize that through education they would have skill to be chosen and being advantage for them to reach what they dream. In addition, the school will create student with high quality and bring the knowledge to the public. The parents will decided and send their children to study due to the reputation of the school itself. The difference among ability or skill 
regarding to the writing can be referred to prove or fence for the teacher and student in teaching learning in the class.

Certainly those different is not appear on education level between one people to another have different each other include in learning English. Besides writing skill, reading skill will develop the reading skill itself through reading activity as same as to train the writing activity through writing practice. Through practicing, it will help student to improve writing skill and to figure out the best strategy for themselves in creating a writing English by using good grammar. This step surely can be found the location or the place of mistake what student been wrote by using grammar.

Recently people assume between grammar and structure has similar form. People are bale to write sentence without thinking about grammar they wrote. The fact is totally different because grammar is focused on the way to write it and the other side structure more focus on form of the sentence and time of the event. The time in structure know as tenses whereas the tenses show about adverb of time recognizing when an event appears, have appear, and will appear. The grammar and structure are two units cannot be separate in making of sentence.

The grammar consists of subject, predicate, an object, and adverb of time, place, or manner. Grammar and structure are an important point for English active communicating whether orally or write. Learning writing have to think carefully and accurately while make some good English sentence. Writing is a complexity process involving high mentality such as memorizing, imagination, arrangement, applied, and problem solve. Writing skill generally is acquired by unique skill and has important role developing the knowledge, communication tools for people. It because not all people are able to improve the skill they have as a tool to inventive themselves or more than that being culture for them own selves.

It needs some examination to measure how far student mastery of grammar called skill test. This test usually applied in reviewing the materials or having test English proficiency. The difficulties of student may be found while they learnt English grammar area. This can be happened of student result why do the student. It can thus be argued that fluency English generally - a with case, whether in grammar or writing, and the ability to understand what he or she hears and reads - can be measured by learning and test which evaluate performance in language skills.

Students should recognize of grammar mastery that it can be found through the writing the made.
Writing can be inferred to add the knowledge about everything plus the grammar itself, how to set the paragraph, topic chosen, the language style, and the main idea. By these circumstances of learning grammar, it acquired motivation of learning in English to assist student easier in facing the difficulties of understanding the grammar.

The habit of writing and understanding of grammar are those rarely comprehend by Indonesian people. This means caused by several things such as no culture-style of grammar mastery, unassisted an environment around. Writing skills have some purposes include involving the structure and grammar, raising the grammar, adding of grammar, having information of something or enjoying the literature masterpiece. In learning of language many factors should teacher noticed so purpose of the grammar mastery will be reached as well. Teacher is delivering the course can use any method of learning and also an appropriate approach based on the condition in the class and the students as well. This hopes the result of student learning especially of grammar has significantly reached.

The student of SMK Selagan Jaya Jakarta is still may found of mistaken in grammar mastery while write of English. The student always do mistake in completing some task of exercise especially in writing. Grammar is always as a top of lack in making of good writing due to grammar incorrect. By the information given above, it is important to look for how to increase the student learning result toward of grammar mastery in English writing and to find any effect of grammar toward writing English skill.

\section{METHOD OF RESEARCH}

This paper uses quantitative research method. It means the paper shown the data by using statistically form seeking an answer of problem been researched, (Kountur 2007:105). The form of $X$ as independent variable can be viewed as a grammar while $\mathrm{Y}$ as dependent and represent of writing skill. The population in SMK Selagan Jaya is 47 students. Based on Arikunto references which is the sample used consisting of 20 students chosen randomly. The source of the data is taken from the result of grammar test and writing test. The research is shown the correlation between the variable of the object research. The technique of collecting data is chosen by using 20 multiple choice of grammar tests and five numbers of essay writing test.

\section{Research Design}

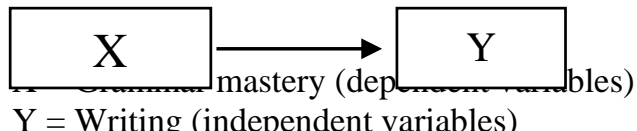

$\mathrm{Y}=$ Writing (independent variables) 


\section{FINDING AND DISCUSSION}

\section{A. Data Description}

1. Data of Grammar Mastery

The data of grammar mastery is given by the test of grammar-twenty multiple choices at tenth grade SMK Selagan Jaya. This test has had 96 as highest score and 56 as smallest score. Next, the mean can be counted as a follow:

a. Determine of distributing frequently

1. Determine the distance $(\mathrm{R})$ begins the bigger onto the smallest: $\mathrm{R}=96-40=40$

2. Determine the length of class $(\mathrm{K})$ by Struges's rule $K=1+3,3 \log n$

$$
\begin{aligned}
& =1+3,3(20), 1+3,3 \log (1,30)=5,29 \\
& \quad \text { or } 6
\end{aligned}
$$

3. Determine the length of class interval (P) $\mathrm{P}=\frac{40}{6}=6,67$ or 7

Table 1. Grammar's result Distributing of Frequency

\begin{tabular}{|c|c|c|c|c|c|c|c|}
\hline No & Interval & $\mathbf{F i}$ & $\mathbf{f k u m}$ & $\mathbf{X i}$ & $\mathbf{X i}^{2}$ & $\mathbf{f i X i}$ & $\mathbf{f i X i}^{2}$ \\
\hline 1 & $56-62$ & 7 & 7 & 59 & 3481 & 413 & 170569 \\
\hline 2 & $63-69$ & 3 & 10 & 66 & 4356 & 198 & 39204 \\
\hline 3 & $70-76$ & 2 & 12 & 73 & 5329 & 146 & 21316 \\
\hline 4 & $77-83$ & 2 & 14 & 80 & 6400 & 160 & 25600 \\
\hline 5 & $84-90$ & 2 & 16 & 87 & 7569 & 174 & 30276 \\
\hline 6 & $91-97$ & 4 & 20 & 94 & 8836 & 376 & 141376 \\
\hline & $\Sigma$ & 20 & & 459 & 35971 & 1467 & 428341 \\
\hline
\end{tabular}

b. Mean $\quad=\frac{\sum F X}{n}=\frac{1467}{20}=73,3$

c. Median $=\mathrm{b}+\mathrm{p}\left[\frac{\frac{n}{2} F}{f}\right]=62,5+7 \frac{\frac{1}{2} 20-7}{3}=69,5$

d. Modus $=\mathrm{b}+\mathrm{p}\left[\frac{d 1}{d 1+d 2}\right]=55,5+7\left[\frac{7}{7+4}\right]=$

$\begin{aligned} 55,5+7 & (0,63)=59,91 \\ \text { e. Standar deviation } & =\sqrt{\frac{\sum(X-\bar{x})^{2}}{n}}\end{aligned}$

$\sqrt{4028,8}$

$=\sqrt{\frac{4028,8}{19}}$

$=14,56$

f. Varians $=14,56^{2}=211,99$

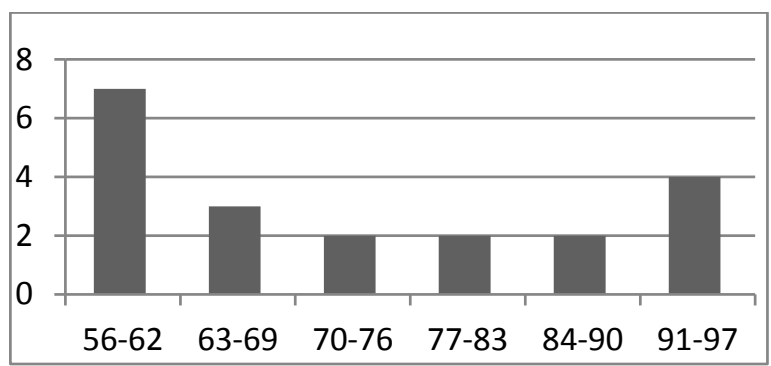

Figure 1. The Graph of Grammar Mastery
Based on the result above it said that from twenty students were found the highest score 96 and the lowest 56, from the counting result said was found an average 73,3 , the median 69,5 , the modus 59,91, and deviation standards 14,56 . The whole data can be concluded that the data was good as a result.

2. Data of Writing Skill

The data of writing is taken from grammar test of five numbers of essay tests. The result of the test is 92 as the highest score of grammar and 52 as smallest score. It can be continued to seek Mean and the steps for the rest of scoring:

a. Determine of distributing frequently

1. Determine the distance $(\mathrm{R})$ begins the biggest into the smallest:

$\mathrm{R}=92-52=40$

2. Determine the length of class $(K)$ by Struges's rule

$$
\begin{aligned}
\mathrm{K} & =1+3,3 \log \mathrm{n} \\
& =1+3,3 \log (20) \\
& =1+3,3 \log (1,30) \\
& =1+4,29=5,29 \text { or } 6
\end{aligned}
$$

3. Determine the length of class interval (P) $\mathrm{P}=\frac{r}{k}=\frac{40}{6}=6,67$ or 7

Table 2. Writing result of distributing frequency

\begin{tabular}{|c|c|c|c|c|c|c|c|}
\hline No & Interval & Fi & fkum & $\mathbf{X i}$ & $\mathbf{X i}^{2}$ & fiXi & $\mathbf{f i X i}^{\mathbf{2}}$ \\
\hline 1 & $52-58$ & 7 & 7 & 55 & 3025 & 385 & 148225 \\
\hline 2 & $59-65$ & 5 & 12 & 62 & 3844 & 310 & 96100 \\
\hline 3 & $66-72$ & 1 & 13 & 69 & 4761 & 69 & 4761 \\
\hline 4 & $73-79$ & 2 & 15 & 76 & 5776 & 152 & 23104 \\
\hline 5 & $80-86$ & 2 & 17 & 83 & 6889 & 166 & 27556 \\
\hline 6 & $87-93$ & 3 & 20 & 90 & 8100 & 270 & 72900 \\
\hline & $\Sigma$ & 20 & & 435 & 32395 & 1352 & 372646 \\
\hline
\end{tabular}

b. Mean

$$
=\frac{\sum F X}{n}
$$$$
=\frac{1352}{20}
$$$$
=67,6
$$

c. Median

$$
=\mathrm{b}+\mathrm{p}\left[\frac{\frac{n}{2} F}{f}\right]
$$$$
=58,5+7 \frac{\frac{1}{2} 20-7}{5}
$$$$
=58,5+7(0,6)
$$$$
=58,5+(4,2)
$$$$
=62,7
$$

d. Modus

$$
=\mathrm{b}+\mathrm{p}\left[\frac{d 1}{d 1+d 2}\right]
$$

$$
\begin{aligned}
& =51,5+7\left[\frac{7}{7+2}\right] \\
& =51,5+7(0,77) \\
& =51,5+5,39 \\
& =56,89 \text { or } 60
\end{aligned}
$$

$$
\begin{aligned}
\text { e.Standard deviation } & =\sqrt{\frac{\sum\left(X-\overline{x)^{2}}\right.}{n}} \\
& =\sqrt{\frac{3539,2}{19}} \\
& =\sqrt{186,27}
\end{aligned}
$$


$=13,65$
f. Varians
$=13,65^{2}=186,32$

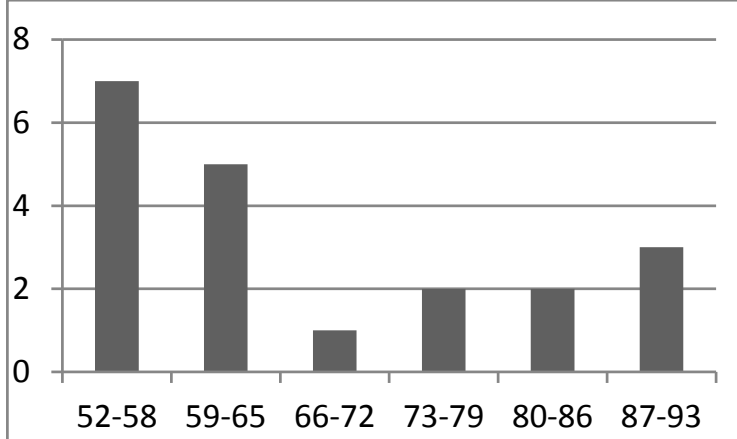

Figure 2. Graph of Writing

According to the result above it can be declared that from 20 students has 92 as the highest score and 52 as smallest score and from the resulting of calculation can be found the Mean 67,6, median 62,7 , modus 60 , and standard deviation 13,65 . These were shown the data can be well categorized.

B. Technique of Prerequisite Data Analysis

In order to have significant and accurate data of this research, it required normality test of each variables to know whether both variable are having normal distributing. The next steps, both variables will be examined of coefficient regression and correlation. The coefficient data is a data take from grammar and writing test. This method used to know how correlation between grammar mastery and writing skill.

\section{Normality Test Data}

The test for normality will use to know whether the data is taken from the population normal distribution or not. The criteria of normality test are $\mathrm{H}_{0}$ accepted if $\mathrm{L}$ count smaller than $\mathrm{L}$ table. This means the data of the research takes from population normal distribution. After the writer finished the calculation of normality test of grammar mastery then it was found the data shown $\mathrm{L}$ count has 0,23 and $\mathrm{L}$ table with $\alpha=0,05$ has 0,190 and $\alpha=0,01$ has 0,231 . However, this can be concluded the sample was taken from normal population. Next step, it will counted of writing English test whereas found $\mathrm{L}$ count has 0, 09 and $L$ table with $\alpha=0,05$ was 0,190 and $\alpha=0,01$ was 0,231 . It can be concluded of writing English test that the sample was taken from normal population.

The next table shows $\mathrm{L}$ count 0,23 and $\mathrm{L}$ table with $\alpha=$ 0,05 is 0,190 , and $\alpha=0,01$ is 0,231 . This can be concluded the sample' source of the population is normal distribution.
Table 3. Normality Test of Grammar

\begin{tabular}{|c|c|c|c|c|c|c|c|c|}
\hline No & Grade & Score & $\mathrm{x}-\mathrm{X}$ & $(\mathrm{x}-\mathrm{X})^{n}$ & $z$ & $\mathrm{~F}(\mathrm{z})$ & $\mathrm{S}(\mathrm{z})$ & $\mathbf{F}(\mathrm{z})-\mathrm{S}$ \\
$(\mathrm{z}) \mathrm{I}$
\end{tabular}

Table 4. Normality Test of Writing

\begin{tabular}{|c|c|c|c|c|c|c|c|c|}
\hline No & Grade & Score & $x-x$ & $\left(x-x y^{n}\right.$ & $z$ & $F(x)$ & $S(x)$ & $\begin{array}{c}\text { If }(z)-S \\
\text { (z)I }\end{array}$ \\
\hline $\mathrm{t}$ & 13 & 52 & -15.2 & 231.04 & -104 & 0.149 & 0.15 & 0.00 \\
\hline 2 & 13 & 52 & -15.2 & 231.04 & -1.04 & 0.149 & 0.15 & 0.00 \\
\hline 3 & 13 & 52 & -15.2 & 231.04 & -1.04 & 0.149 & 0.15 & 0.00 \\
\hline 4 & 14 & 56 & -11.2 & 125.44 & -0.77 & 0209 & 0.30 & 0.09 \\
\hline 5 & 14 & 56 & -11.2 & 125.44 & -0.77 & 0.209 & 030 & 0.00 \\
\hline 6 & 14 & 36 & -11.2 & 125.44 & -0.77 & 0.209 & 0.30 & 009 \\
\hline 7 & 14 & 56 & -11.2 & 125.44 & -0.77 & 0.284 & 0.45 & 0.17 \\
\hline 8 & 15 & 60 & -7.2 & 51.54 & -0.49 & 0.284 & 0.45 & 0.17 \\
\hline 9 & 15 & 60 & -7.2 & 51.84 & -0.49 & 0.284 & 0.45 & 0.17 \\
\hline 10 & 16 & 64 & -3.2 & 10.24 & 022 & 0.371 & 0.50 & 0.13 \\
\hline 11 & 16 & 64 & -3.2 & 10.24 & -0.22 & 0.464 & 0.55 & 0.09 \\
\hline 12 & 16 & 64 & -3.2 & 10.24 & -0.22 & 0.552 & 0.65 & 0.10 \\
\hline 13 & 17 & 68 & 0.8 & 064 & 0.05 & 0.552 & 0.65 & 0.10 \\
\hline 14 & 18 & 72 & 4.8 & 23.04 & 0.33 & 0.802 & 0.50 & $0 \infty 0$ \\
\hline 15 & 19 & 76 & 8.8 & 77.44 & 0.60 & 0.802 & 0.80 & 0.00 \\
\hline 16 & 20 & 80 & 128 & 163.84 & 0.88 & 0.802 & 0.50 & 000 \\
\hline 18 & 22 & 88 & 20.8 & 432.64 & 1.43 & 0.862 & 090 & 004 \\
\hline 19 & 23 & 92 & 24.8 & 615.04 & 1.70 & 0908 & 100 & 009 \\
\hline 20 & 23 & 92 & 24.8 & 615.04 & 1.70 & 0908 & 1.00 & 009 \\
\hline & Total & 1344 & & 3539.2 & & & & \\
\hline & Avarage & 67.2 & & & & & & \\
\hline
\end{tabular}


The table above shows $\mathrm{L}$ count 0,09 and $\mathrm{L}$ table with $\alpha$ $=0,05$ is 0,190 , and $\alpha=0,01$ is 0,231 . This can be concluded the sample' source of the population is normal distribution. The next steps will do test of linearity from this sample.

\section{Linearity Regression Test}

Table 5. Coefficient Regression Test and Product Moment Correlation

\begin{tabular}{|c|c|c|c|c|c|}
\hline $\begin{array}{c}\text { The } \\
\text { Respondent }\end{array}$ & $\mathbf{X}$ & $\mathbf{Y}$ & $\mathbf{X Y}$ & $\mathrm{X}^{2}$ & $\mathbf{Y}^{2}$ \\
\hline 1 & 96 & 92 & 8832 & 9216 & 8464 \\
\hline 2 & 96 & 92 & 8832 & 9216 & 8464 \\
\hline 3 & 92 & 88 & 8096 & 8464 & 7744 \\
\hline 4 & 92 & 84 & 7728 & 8464 & 7056 \\
\hline 5 & 88 & 80 & 7040 & 7744 & 6400 \\
\hline 6 & 84 & 76 & 6384 & 7056 & 5776 \\
\hline 7 & 80 & 72 & 5760 & 6400 & 5184 \\
\hline 8 & 76 & 68 & 5168 & 5776 & 4624 \\
\hline 9 & 72 & 64 & 4608 & 5184 & 4624 \\
\hline 10 & 72 & 64 & 4608 & 5184 & 4096 \\
\hline 11 & 68 & 64 & 4352 & 4624 & 4096 \\
\hline 12 & 64 & 60 & 3840 & 4096 & 3600 \\
\hline 13 & 64 & 60 & 3840 & 4096 & 3600 \\
\hline 14 & 60 & 56 & 3360 & 3600 & 3136 \\
\hline 15 & 60 & 56 & 3360 & 3600 & 3136 \\
\hline 16 & 60 & 56 & 3360 & 3600 & 3136 \\
\hline 17 & 56 & 56 & 3136 & 3136 & 3136 \\
\hline 18 & 56 & 52 & 2912 & 3136 & 2704 \\
\hline 19 & 56 & 52 & 2912 & 3136 & 2704 \\
\hline \multirow[t]{3}{*}{20} & 56 & 52 & 2912 & 3136 & 2704 \\
\hline & 1448 & 1344 & 101040 & 108864 & 93856 \\
\hline & $\sum X$ & $\sum \mathrm{Y}$ & $\sum X Y$ & $\sum X^{2}$ & $\sum \mathrm{Y}^{2}$ \\
\hline
\end{tabular}

In searching of regression similarity by using $\hat{Y}=a$ $+\mathrm{bx}$. This formulation can be form to count coefficient regression test and correlation product moment as a follow:

$$
\begin{aligned}
\mathrm{a} & =\frac{1344(108864)-1448(101040}{20(108864)-(1448)^{2}} \\
& =\frac{1446313216-146305920}{2177280-2096704} \\
& =\frac{7296}{80576} \\
& =0,091
\end{aligned}
$$

b

$$
\begin{aligned}
& =\frac{20(101040)-1448(1344)}{20(108864)-(1448)^{2}} \\
& =\frac{2020800-1946112}{2177280-2096704} \\
& =\frac{74688}{80576} \\
& =0,93
\end{aligned}
$$

The $\mathrm{X}$ and $\mathrm{Y}$ of regression linearity have similarity $\hat{Y}=0,091+0$, 93. An $X$ variable or the grammar mastery and a $\mathrm{Y}$ variable or writing English is straight equivalent and to be positive position if an $\mathrm{X}$ has positive, so will produced Y positive, and having the correlation which is regressed to each other.

C. Hypothesis Test

1. The coefficient looks for a correlation product moment counting by using this following formulation:

$\mathrm{r} x \mathrm{y}=$

$$
\begin{aligned}
& \frac{n \cdot(\Sigma x y)-(\Sigma x) \cdot(\Sigma y)}{\left.\sqrt{\left\{n \cdot \Sigma x^{2}-\left(\Sigma[x)^{2} \bar{z}\right\} \cdot\left\{n \cdot \Sigma y^{2}-\left(\sum[y)^{2} \rrbracket\right.\right.\right.}\right\}} \\
& \operatorname{rxy}=\frac{20(101040)-1448(1344)}{\sqrt{\left\{20.108864-(1448)^{2}\right\}\left\{20.93856-(1344)^{2}\right\}}} \\
& =\frac{2020800-1946112}{\sqrt{\{2177280-2096704\}\{1877120-1806336\}}} \\
& =\frac{74688}{\sqrt{80576.70784}}=\frac{74688}{\sqrt{5703491584}} \\
& =\frac{74688}{75521,46}=0,9889
\end{aligned}
$$

2. The significant Count

$$
\begin{gathered}
t_{\text {hitung }}=\frac{r \sqrt{n-2}}{\sqrt{1-r^{2}}}=\frac{0,9889 \sqrt{20-2}}{\sqrt{1-0,9889^{2}}}=\frac{0,9889 \sqrt{18}}{\sqrt{1-0,977}} \\
=\frac{0,9889 \sqrt{18}}{\sqrt{0,023}}=\frac{4,196}{\sqrt{0,023}}=27,66
\end{gathered}
$$

3. Coefficient Determination

$$
\begin{aligned}
& \mathrm{CD}=r^{2} \times 100 \%=0,9889^{2} \times 100 \%= \\
& 97,8 \%
\end{aligned}
$$

It can be concluded that grammar mastery gives significant contribution of $97,8 \%$ to the writing skills.

D. Testing of Hypothesis

This research is trying to find out he effect of grammar toward writing skill of tenth grade student of SMK Selagan Jaya Jakarta. Based on the analysis above been done, it can be interpreted that there is an effect of grammar toward writing skill with the score 0,9889 . This point is higher enough so can be concluded it is having highest effect, plus the contribution additional of grammar variable is 97 , $8 \%$.

The grammar mastery is one of important thing of language skills to assist student able to understand English during teaching learning processes in the class. If the student is lacked of grammar so they cannot do write well of English writing.

The point of this analysis can be taken if the score of grammar test whether high or low on the progress must be have the correlation or effected by whether high or low of the writing test result. 
E. The Result Interpretations

The confession correlation through analysis result shows the data of 0,9889 which is mean above the table grade. The table grade on the standard significant $5 \%$ is 0,444 . This condition concludes the zero hypothesis of the research is acceptable.

There are some statements to indicate whether having the effect between grammar mastery variable with writing skills of student grade X SMK Salagan Jakarta.

1. There are significant different of student ability in accomplishing an assignment. The student who has highest score of grammar mastery is similarity having highest score of writing skill. Moreover, the student who has lowest score of grammar mastery will having lower score also to writing skill. This means grammar mastery have effect to writing skill.

2. Meanwhile, the student who has highest score of grammar mastery having also better skill rather than student who has lowest score. This shows the grammar's role help student to increase their ability in writing of English.

\section{CONCLUSION}

This research expresses of empiric data of grammar mastery and writing skill of student grade X of SMK Selagan Jaya Jakarta. From the result by using correlation product moment can be concluded that there are effect between grammar mastery to writing skill. The conclusion as a follow:

1. The grammar mastery (X) have lowest score 56, highest 96, average score 73,3, modus 59,91, median 68,5 , and standard deviation 14,56 . It can be referred that the standard of assessment or the scale can be categorized as sufficient scale.

2. Writing skill (Y) have found the highest score 92 , lowest 52 , average score 67,6 , modus 60 , median 62, 7, and standard deviation 13,65 . It can be referred that the standard assessment can be categorized as sufficient scale.

\section{REFERENCES}

Departemen Pendidikan Nasional. (2008). Aktif berbahasa Indonesia. Jakarta: Pustaka perbukuan, Jakarta.

Eddie, Kristbjorg. Writing With The Lights on Form Sentences to Paragraph. New Jersey: Prentice Hall. 1996.

Finnochiaro, Mary. (1974). English as a Second Language: From Theory To Practice. New York: Regents Publishing Company.

Finnochiaro, Mary Bonomo, Michael Bonomo. (1973). The Foreign Language Learner A
Guide For Teachers. New York: Regent Publishing Co.

Halliday, M.A.K (1999). An Introduction To

Functional Grammar. London: Edward Arnlold of The Hodder Headline Group.

Krashen, Stephen D, Tracy D. Terrel. (1983). The Natural Approach. London: Prentice Hall Europe

Revell, Jane. (1979). Teaching Tehnique For Communicative English. New York: Prentice Hall

Randolph, Quirk. (1985). A comprehensive grammar of English language. New York: Cambridge university press.

Rivers, Wilga M. (1981). Teaching Foreign Language Skills. Chicago: University of Chicago Press

Sugiyono. (2002). Statistika Untuk Penelitian. Bandung : Alfabeta.

Suharismi, Arikunto. 2002. Prosedur

Penelitian Suatu Pendekatan Praktek. Jakarta: Rineka Cipta.

Thornbury, Scott. (1999). How To Teach Grammar. New York: Bluestone Press.

\section{PROFILE}

Jimmi, M.Pd born at Bangka province, January $10^{\text {th }}$ 1982. He Graduated from Strata 1 of Pendidikan Bahasa Inggris University of Indraprasta PGRI on 2010. The writer continued his study at same University to take Magister Pendidikan bahasa Inggris on 2012 and graduated on May 2014. As English lecturer in ABA BSI Jakarta, the writer teaches English Psychology, Lab. English for Business, Listening Comprehension, pronunciation. The writer also as Head of Lembaga Bahasa BSI from September 2017 until August 2018. 